удК 655.3066.36-044.9; 762.21

( Т. Ю. Киричок, д.т.н., професор, Я. В. Герук, аспірантка, КПІ ім. Ігоря Сікорського, Київ, Україна

\title{
СУЧАСНІ ТЕНДЕНЦІЇ ДРУКОВАНОЇ СУВЕНІРНОЇ ПРОДУКЦІЇ БАНКНОТНО-МОНЕТНИХ ДВОРІВ СВІТУ
}

Проведено дослідження та аналіз сучасних тенденцій та підходів у виборі зображень для друкованої сувенірної продукції, що виготовляється Банкнотно-монетними дворами світу. Результати досліджень показують, що у більшості країн світу, а насамперед в Україні, Банкнотно-монетні двори не виготовляють іміджеву друковану сувенірну продукцію, зокрема інтагліодруком.

Тому, розвиток цієї теми є сучасним, перспективним та конкурентноспроможним, де головною ідеєю буде висвітлення національної ідентичності країни, її історії та культури, видатних діячів та знаменних подій, дат на державному рівні.

Ключові слова: інтагліодрук; офорт; глибокий друк; зображення; друкована сувенірна продукція; банкноти;

Банкнотно-монетний двір.

\section{Постановка проблеми}

В Україні і світі особливого значення набуває проблема виготовлення якісної іміджевої друкованої сувенірної продукції, що може конкурувати з художніми творами, виконаними способом гравіювання, що передбачає собою довготривалий та затратний процес виконання. Саме металографічний або інтагліодрук, що використовується виключно для виготовлення цінних паперів і документів суворого обліку, особливо банкнот, дозволяє отримати відбитки різноманітних півтонів, також рельєфне зображення, яке можна перевірити на дотик. Це дає змогу прирівняти за художніми якостями відбитки зображень, надрукованими у техніці офорту та інтагліодруку. Але інтагліо - це метод друку обмеженого доступу, який вирізняється високою собівартістю, тому важливо обґрунтовано підійти до вибору матеріалів для друку (здешевлення фарб та паперу) та певних автентичних захисних елементів на сувенірній продукції.

Слід зазначити, що проблема виготовлення друкованої сувенірної продукції інтагліо способом не досліджена науковцями, тому такі дослідження, зважаючи на перспективність випуску подібної сувенірної продукції, $є$ актуальними.

\section{Мета роботи}

Вивчення сучасних тенденцій вибору зображень для друкованої

(C) $2017 \mathrm{p}$. 
сувенірної продукції та технологій їх друку Банкнотно-монетними дворами світу та визначення на цій основі напрямків розроблення зображень для друкованої сувенірної продукції, що може бути використана Банкнотномонетним двором Національного банку України.

\section{Аналіз попередніх досліджень}

Переважний напрямок сувенірної продукції банкнотних дворів світу - пам'ятні сувеніри у вигляді купюр та нерозрізаних аркушів з надрукованими купюрами.

До 50-ї річниці незалежності Мальдівів у 2015 р. Валютне управління Мальдівських островів [1] випускає пам'ятний сувенір у вигляді купюри у вишуканому подарунковому пакованні. Головна ідея - зобразити прогрес та мир за 50 років незалежності країни.

Виданню притаманний унікальний дизайн, майстерність виконання, орнамент характеризує традиції та ісламські звичаї Мальдівів (рис. 1) [1].

Колірна гама банкнот Мальдів - світлих пастельних кольорів, стримана, вишукана, описує національні цінності.
Серія банкнот Мальдівських островів вважається одними з найкрасивіших банкнот світу. Дизайн грошових одиниць ідентифікує країну, висвітлюючи унікальність її природи, нації та культури. Ця серія в обігу з 26 січня 2016 року. Банкноти можна придбати, як сувенірні видання. Для цього передбачені паковання у вигляді паперового чи шкіряного альбому чи буклету відповідно (рис. 1) [1].

Резервний банк Австралії також практикує випуск пам'ятних колекційних банкнот у подарунковому пакованні [2]. У Австралії такі сувеніри досить популярні і пропонують цікавий погляд на австралійську культуру, історію та цінності (рис. 2).

Також, вирізняються $з$ поміж інших банкнот своїм дизайном, оригінальністю та доцільністю оформлення, банкноти Казахстану. До 20-ти річчя національно валюти, вийшла в обіг нова купюра, що має вертикальний символічний дизайн (рис. 3). На банкноті зображені крилатий кінь, як символ чистого світла і життя, натхнення і родючості, цілеспрямованості і влади та тріумфальну арку як символ вільної країни, національної ідеї [3].

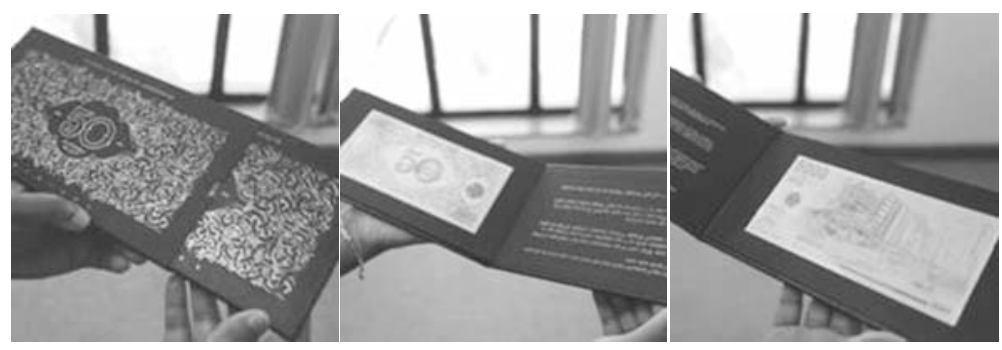

Рис. 1. Пам'ятний сувенір до 50-ї річниці незалежності Мальдівів, 2015 р., інтагліодрук [1] 


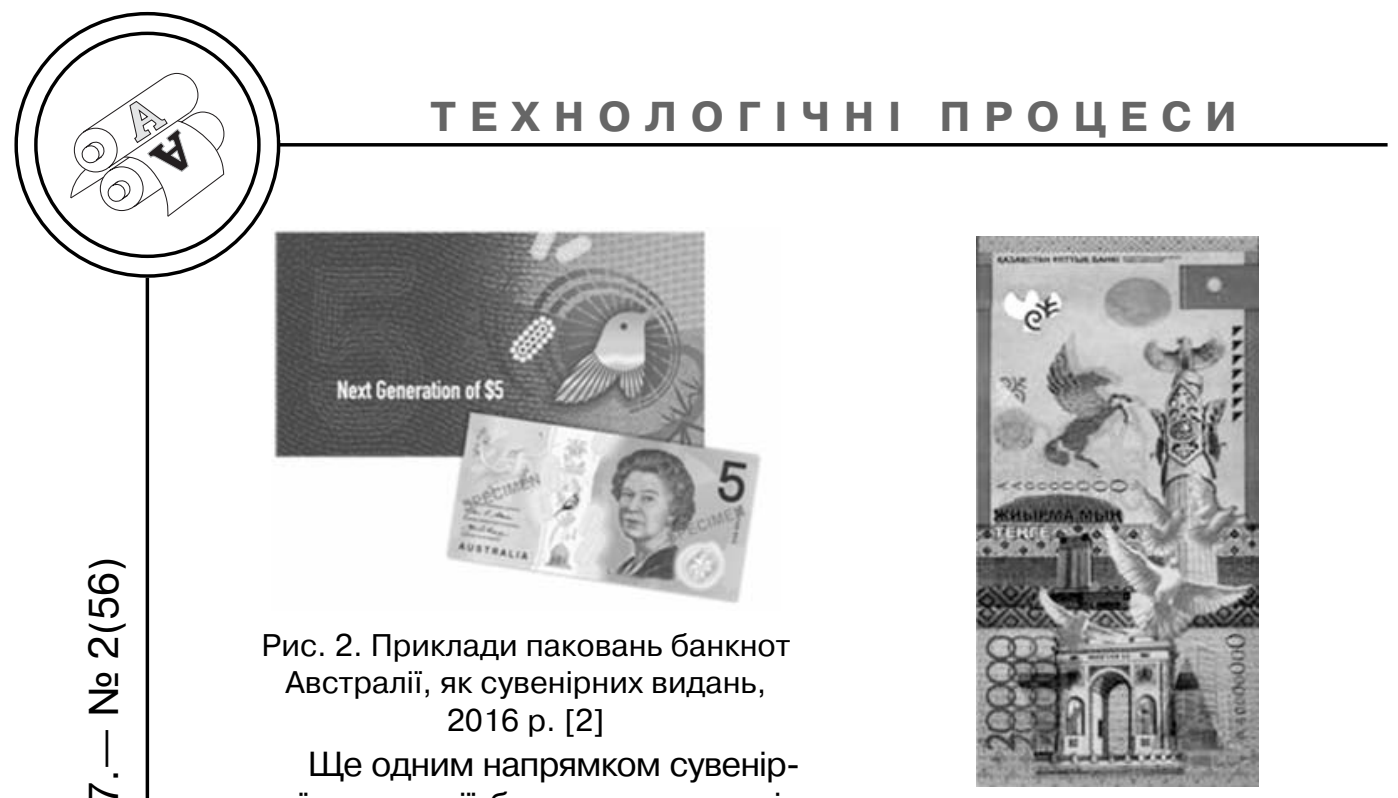
ної продукції банкнотних дворів світу $€$ виготовлення графічної сувенірної продукції. Окремі національні виробники банкнот світу обрали інтагліодрук не тільки для виготовлення та захисту грошових одиниць і цінних паперів, a i для виготовлення іміджевої друкованої сувенірної продукції.

Розглядаючи глибокий друк, а саме гравюру на металі, з художньої точки зору, можна виділити декілька її різновидів. Це акватинта, меццо-тинто, м'який лак, офорт, суха голка та ін.

Суха голка - це техніка гравіювання на металі, де відсутнє травлення. Зображення виконується вістрям твердої голки на поверхні металевої дошки. Отримана дошка $є$ формою глибокого друку. Штрихам характерна м'якість. Техніка сухої голки простішата доступніша офорту, адже не потрібно, ні ґрунтування, ні травлення. Штрихи наносяться безпосередньо на відполіровану мідну або цинкову дошку художником [4].

Акватинта та м'який лак це різновиди техніки офорту [5]. В обох випадках потрібно ґрунтування поверхні металевої пластини та травлення кислотою.

\section{Рис. 3. Банкнота Казахстану, випущена до 20-ти річчя} національно валюти у 2005 р. [3]

Відрізняються певні інгредієнти в технологічних процесах, що дає цікаві ефекти: у акватинті малюнок схожий на акварельний живопис; у м'якому лаку штрих олівця [6].

Офорт - один з різновидів гравюри, метод глибокого друку, де зображення створюють способом механічного гравіювання на металі різцями художником, поглиблення елементів штрихів друкарської форми досягають хімічно, шляхом травлення металу кислотами. Метод відомий ще з початку XVI ст. Техніка виготовлення пластини для друку зображення трудомістка та довготривала: на металеву пластину наносять кислостійкий лак; сталевою голкою гравіюють шар лаку до металу, потім пластину вміщають у кислоту. Травлення можна проводити в декілька прийомів. Після першого травлення в місцях, де не було лаку, утворюються незначні поглиблення. Потім місця, які відповідають світлим ділянкам зображення, знову вкривають лаком і вдруге 


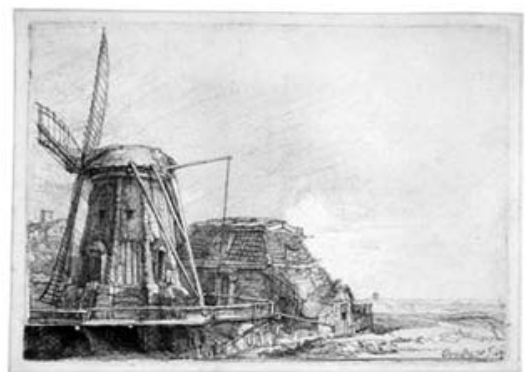

Рис. 4. Рембрант, Вітряк, 1641. Офорт. $14,5 \times 20,5$ см [8]

піддають травленню, поглиблюючи друкувальні елементи, і таким чином за кілька етапів отримують бажану градацію тонів. Для друку фарба закочується в заглиблення, її надлишок знімається. Під дією тиску валу ручного друкарського верстата фарба переходить на папір, утворюючи рельєфні штрихи або тональні плями [7].

Матеріали та інструменти, що необхідні для виготовлення друкарської форми методом офорту це - пластини з цинку, міді або м'якої сталі товщиною від 1,5 до 3 мм, знежирюючий розчинник, твердий або рідкий лак (ґрунт), гасовий або скипидарний факел, кислота; офортні голки, металеві щітки, шабери, гладилки, шліфувальний і полірувальний інструмент, пензель, валик; фарба офортна, папір офортний [5].

Процес створення офорту в техніці травленого штриха складається з наступних етапів: підготовка дошки (шліфування, полірування, ґрунтування і копчення); гравіювання (малювання інструментом по ґрунту); травлення; отримання пробного відбитка; коригування форми; друкування.

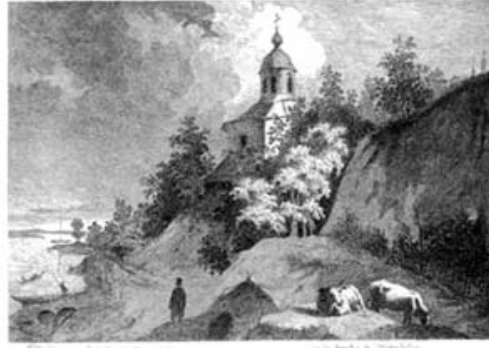

Рис. 5. Т. Шевченко, Видубицький монастир в Києві, 1844.

Папір, офорт 17,1×24,2 см [9]

У техніці офорту працювали видатні художники, такі як Рембрант (1606-1669) (рис. 4), Франсіско Гойя (1746-1828), Тарас Шевченко (1814-1861) (рис. 5) та ін.

Металографічний або інтагліодрук - це спосіб друку з друкарських форм, на яких друкувальні елементи заглиблені по відношенню до пробільних, забезпечує рельєфність елементів зображень, що виступають над поверхнею паперу і шорсткість яких відчувається на дотик. Друк проводиться фарбами підвищеної в'язкості. Фарба, що заповнює заглиблення в друкарській формі під великим тиском (від 80 до 100 кг $/ \mathrm{cm}^{2}$ ) переноситься на задруковуваний матеріал, при цьому вдавлюючись у заглиблення [10].

Метод інтагліодруку на сьогодні $€$ одним з провідних методів захисту банкнот та інших видів цінної друкованої продукції. Відмінні ознаки відбитків інтагліодруку: відсутність растру [8]; товстий шар фарби, що створює рельєф; великий діапазон відтворення відтінків за рахунок різної глибини і ширини штрихових елементів; деформація 
задруковуваного матеріалу (вдавленості зі зворотного боку); характерні витікання фарби («вусики», «шприцювання») по краях штрихів графічних елементів [10].

Технологія глибокого друку, по-перше, моделює фотографічний процес відтворення безперервного (півтонового) зображення i, по-друге, передбачає прямий контакт між матеріалом і формним циліндром, завдяки цьому досягається дуже висока якість друку. Формний циліндр довговічний і витримує великі тиражі [11].

Форми для інтагліодруку виготовляють шляхом електронномеханічного гравіювання, хімічного травлення або прямого лазерного гравіювання [12].

Фарби для друку цінних паперів - спеціально захищені, якість яких суворо контролюється, мають складні характеристики: магнітні та металізовані властивості, містять мікрокапсули, видимі та невидимі в інфрачервоних променях, кольорозмінні під дією хімічних розчинів та температури, водорозчинні та інші [13].

Папір для друку цінних паперів має певні особливості, що гарантують захист документів. Це водяні знаки, планшетки, захисні волокна, металізовані смужки, вміст флуоресцентних частинок, хімічних реактивів, радіоційних мікрочастинок та плівок типу VOID [13].

Для інтагліодруку використовують спеціальне друкарське обладнання 3 обмеженим доступом, що застосовується виключно для виготовлення цінних паперів.
Інтагліодрук може бути цінним у виготовленні друкованої іміджевої сувенірної продукції, адже він максимально може замінити механічний друк художніх творів, виготовлених у складній техніці офорту, що передбачає собою довготривалий та затратний процес виконання.

Зображення, надруковані методом інтагліо мають дорогий вигляд за рахунок чіткості штриху, який можна відчути на дотик.

Найпопулярніші подарункові серії карток надруковані саме інтагліодруком, щорічно виготовляє Бюро гравірування і друку Америки (the Bureau of Engraving and Printing (BEP)), що засноване 1862 р., - це найбільший виробник цінних паперів уряду в Сполучених Штатах Америки. Окрім паперових банкнот, документів суворої звітності, сертифікатів, нагород, ідентифікаційних карток, бланків та інших спеціальних охоронних документів, ВЕР виготовляє високоякісні багатоколірні іміджеві друковані сувеніри способом інтагліо, які можна придбати в інтернетмагазині на офіційному сайті [12]. Ця продукція навіть стала предметом колекціонування.

Вся сувенірна продукція ВЕР присвячена пам'ятним датам, таким як річниці незалежності, річниці видатних діячів, демократії, конституції, подіям, пам'яткам культури США. Така тематика сприяє формуванню поваги до батьківщини на національному рівні та просуванню бренду як США в цілому, так і Бюро гравіювання і друку, зокрема всередині країни та закордоном.

Колірна гама сувенірної продукції стримана здебільшого 


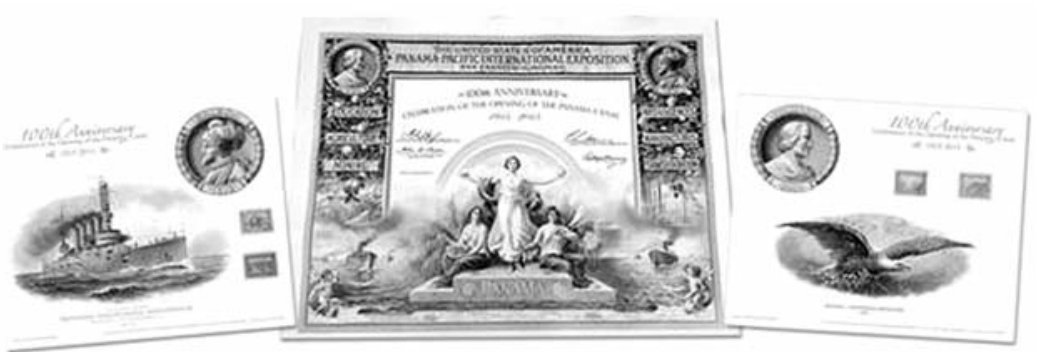

Рис. 6. Серія «Панамський канал Пам'ятна Програма», 2015 р., інтагліодрук [14]

витримана у двох-трьох кольорах, близьких до кольору банкнот.

Друкованим сувенірам притаманне поєднання зображення та супроводжуючого тексту до нього. Використовується як зображення тексту з історичних документів, так і історичні зображення віньєток, рисунків тощо.

Максимально гармонійно підбираються шрифти до графічного матеріалу і до контексту видання (рис. 6).

У 2017 році програма ВЕР випускає колекцію гравірованих художніх композицій, присвячених Конституції Сполучених Штатів (рис. 7). Серія робіт складається з трьох друкованих інтагліодруком видань. За тема- тикою - зображення законодавчих, виконавчих і судових гілок влади федерального уряду.

у Національному бюро друку Японії (National Printing Bureau) [15], технічні експерти в області друку і виготовленні паперу, а також дизайнери та гравери об'єднують свої знання і досвід для створення унікальних сувенірних подарункових друкованих продуктів.

Так, у 2014 році до 100-річчя заснування залізничної станції Токіо, було надруковано серію пам'ятних робіт, що складається 3 двох симетричних гравюр. Права частина роботи зображує станцію Токіо 100-річної давнини, в час відкриття, а ліва сторона показує ту ж будівлю сьогодні.
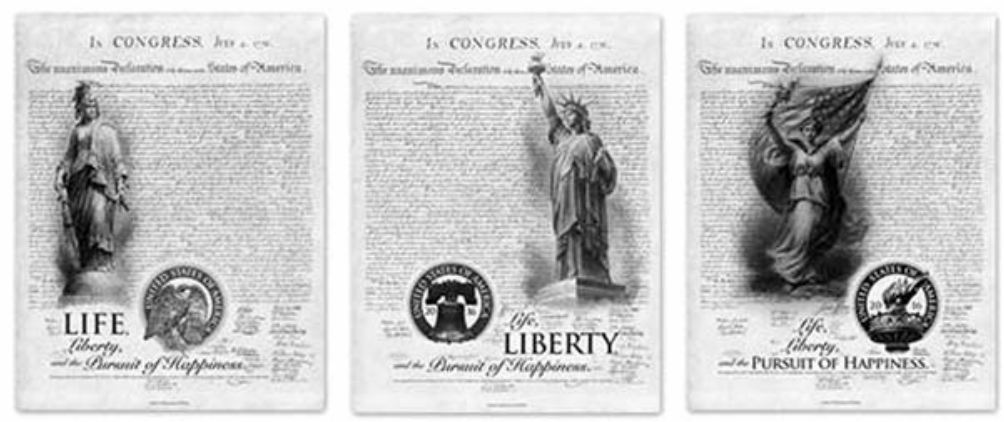

Рис. 7. Серія робіт з назвами - життя, свобода і прагнення до щастя, 2016 р., інтагліодрук [14] 


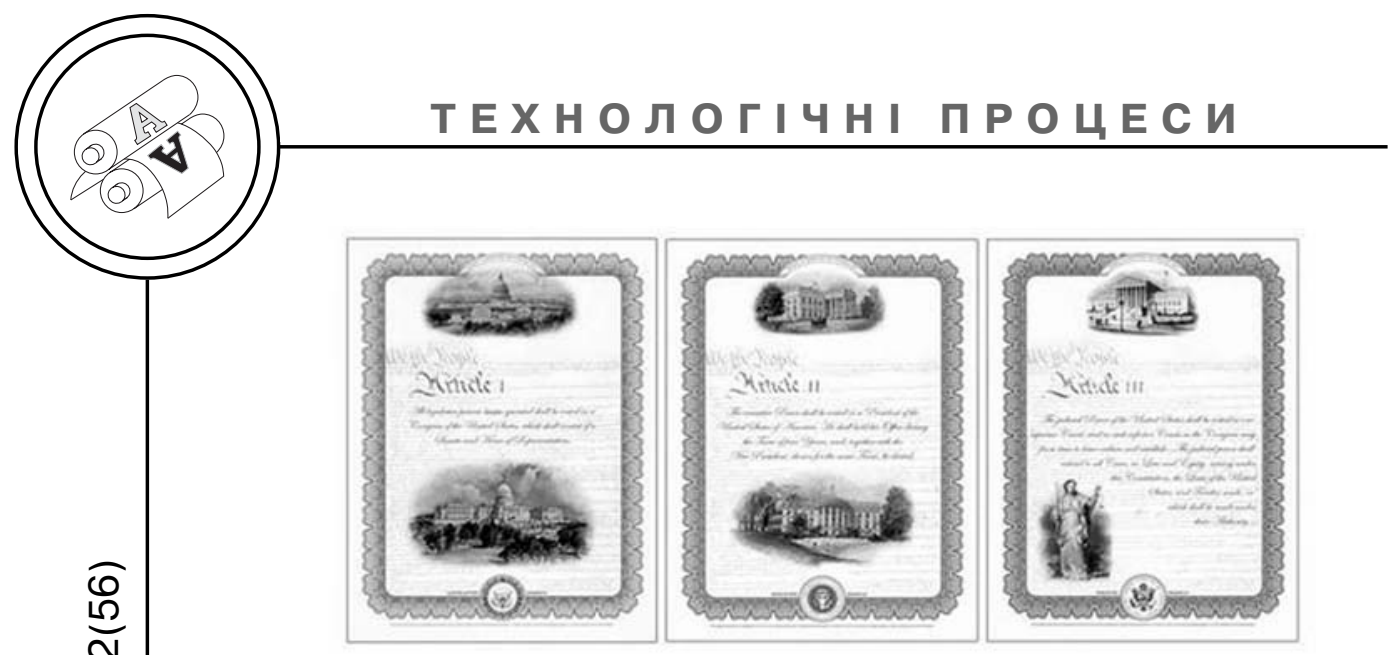

Рис. 8. Серія робіт присвячена Конституції США, 2017 р., інтагліодрук [14]

Надруковано в один колір, що притаманно класичній техніці офорт. На рисунку багато уваги приділено дрібним деталям, високохудожньо здійснено гравіювання (рис. 9, 10).

\section{Результати проведених досліджень}

Аналіз показав, що найбільші банкнотно-монетні двори світу приділяють велику увагу друку якісної іміджевої сувенірної продукції, оскільки саме такого роду сувенірна продукція, з одного боку, підкреслює великі можливості підприємства, з іншого, сприяє просуванню банкнотно-монетного двору як державної установи.

Технологічні можливості способів друку банкнотно-монетних

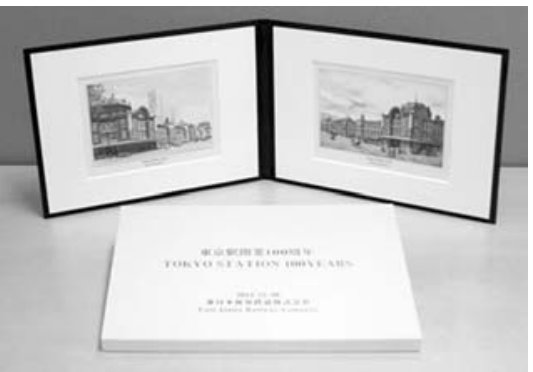

Рис. 9. Памятна робота до 100-річчя станції Токіо, 2014 р., інтагліодрук [15] дворів дуже широкі. Це високий, глибокий, офсетний, орловський, ірисовий, інтагліодрук, трафаретний та комбіновані способи друку. Друкарське обладнання банкнотно-монетних виробництв $є$ обмеженого доступу, що уможливлює створення унікальної сувенірної продукції. Може бути застосований один технологічний процес для друку, а може бути і комбінований, так як для друку цінних паперів.

Для друку сувенірної продукції можуть бути застосовані папір та фарба з особливими елементами захисту, спрощені та без елементів захисту.

Так як і випуск сувенірних банкнот, так і друковані сувеніри

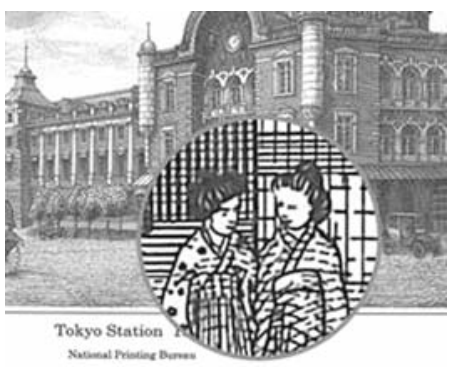

Рис. 10. Пам'ятна робота до 100-річчя станції Токіо (часткове збільшення), 2014 р., інтагліодрук [15] 
можна класифікувати за підставою до випуску. Здебільшого це присвята до пам'ятних дат, визначних подій країни або світу, на замовлення установ та втілення певних ідеологічних цілей.

Ілюстративна наповненість друкованих сувенірів досить широка. Особливе місце займають портретні, пейзажні, предметні, орнаментальні, документальні та семантичні зображення, що мають значення та ступень впізнаваності населенням певного зображення на місцевому, державному або світовому рівнях.

Безпосередньо зображення можуть бути штрихові або тонові; монохромні або кольорові; лінійні, площинні або об'ємні; стилізовані або без стилізації.

Розміщення ілюстрацій на площині друкованої продукції може бути відокремлено по центру, оточено рамкою або текстом, на виліт або змішане.

На основі аналізу друкованої сувенірної продукції банкнотномонетних дворів розроблено класифікацію (рис. 11).

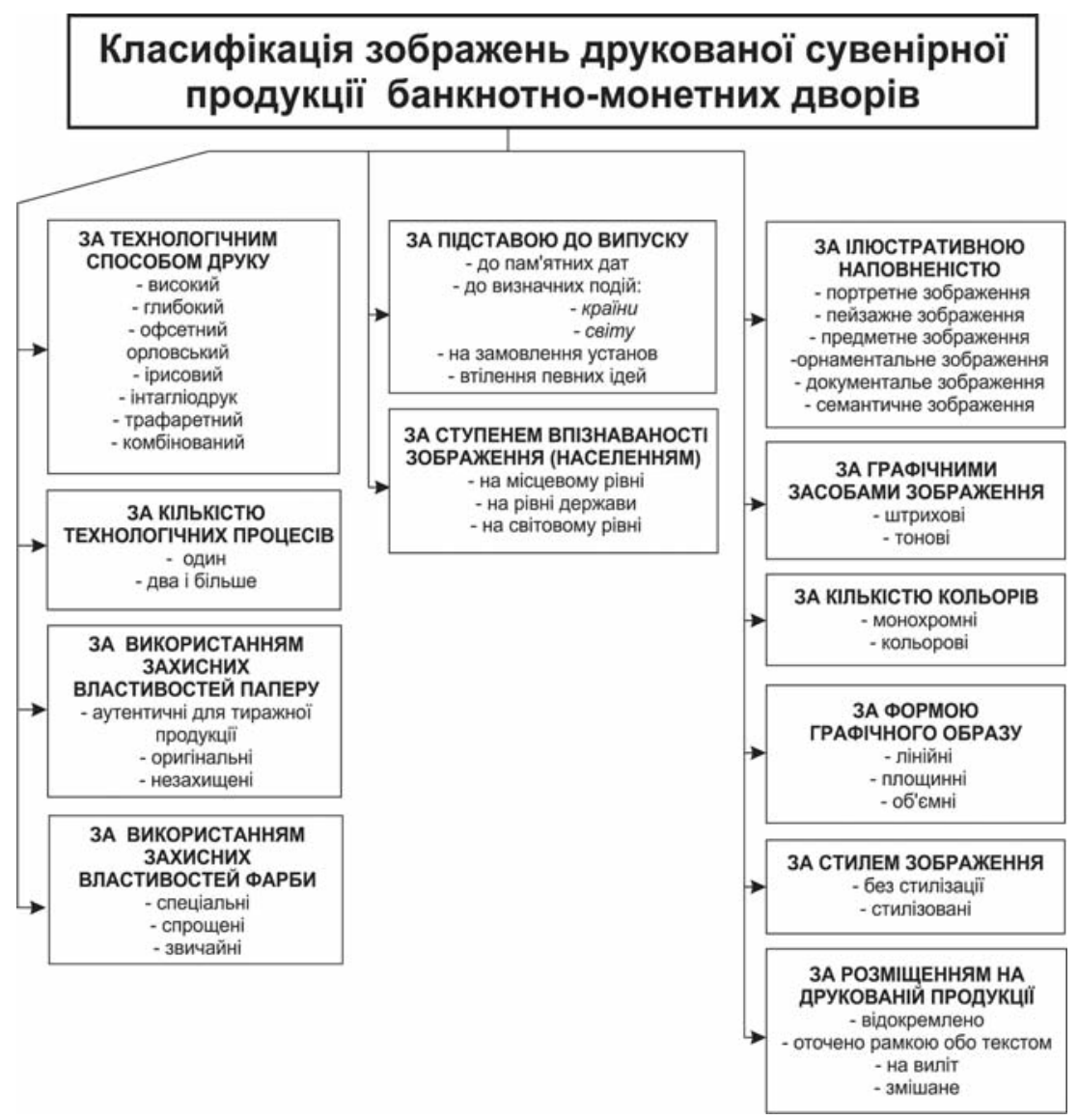

Рис. 11. Класифікація зображень друкованої сувенірної продукції банкнотно-монетних дворів 
Важливо урахувати друкарсько-технічні властивості обладнання та їх адаптація до друку середніх та великих зображень, а також обґрунтований підхід вибору матеріалів, їх здешевлення шляхом вилучення захисних компонентів складу основної фарби та спрощення особливостей паперу.

Вибір тематики зображень для виготовлення друкованої сувенірної продукції в Україні дуже широкий. Цьому сприяє багатолітня історична та культурна спадщина народу. Це можуть бути історичні зображення пейзажів вагомих об'єктів (рис. 12, а), портрети діячів, історичні документи, всесвітньовідомі палеолітичні зображення трипільського народу, зображення декоративно-прикладного характеру, одягу регіонів України, тварини та рослини занесені до Червоної книги України (рис. 12, б) та ін.

\section{Висновки}

Проаналізувавши тенденції вибору графічного матеріалу для сучасних друкованих подарункових видань Банкнотно-монетних дворів світу, можна зро- бити висновок, що головна ідея висвітлення національної ідентичності країни, її історії та культури, видатних діячів та знаменних подій, дат, природи тощо.

Тому саме інтагліодрук може бути цінним у виготовленні друкованої іміджевої сувенірної продукції, адже він максимально якісно може замінити складну механічну техніку офорту, що передбачає собою довготривалий та затратний процес виконання.

Тому виготовлення друкованої продукції інтагліоспособом буде актуально для України, суспільства та туристів, як культурний, іміджевий, високохудожній сувенір на державному рівні.

Для підкреслення автентичності друкованого сувеніра варто використовувати окремі особливі елементи захисту цінних паперів, такі як:

- спеціальні дефекти, мікротекст в друкарській підготовці;

- водяні знаки, захисну стрічку, волокна, флуоресцентні частинки, планшетки та конфеті в паперовій масі;

- елементи, надруковані оптично-змінною, флуоресцентною фарбою та фарбою 3 вмістом мікрокапсул;

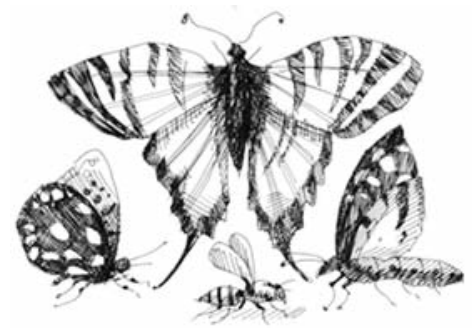

б

Рис. 12. Приклади ескізів для друкованої сувенірної продукції інтагліо способом 
- комбінування спеціальних видів друку;

- зображення з елементами для людей з послабленим зором;

- нанесення голограми;

- нумерація та персоналізація;

- гаряче тиснення;

- ноу-хау.
До вибору теми варто залучати фахівців, щоб вона була актуальною, цікавою та корисною для населення держави та туристам в певний момент розвитку країни.

Доцільно продумати паковання та оформлення друкованого сувеніру, зручність у колекціонуванні, якщо це передбачено.

\section{Список використаної літератури}

1. 50th Independence Comemmorative Note. Maldives Monetary Authority. [Електронний ресурс]. - Режим доступу : http://mma.gov.mv/\#/currency/ numismatic.

2. COLLECTING BANKNOTES. Reserve Bank of Australia. [Електронний pecypc]. - Режим доступу : https://banknotes.rba.gov.au/resources/for-collectors/collecting-banknotes/.

3. Kazhmuratov Zhomart. Innovation and Art in the New 20,000 Tenge Note / Zhomart Kazhmuratov // Proceedings of the Pan European High Security Printing Conference (Milan, Italy, February 17-19, 2014). - Sunbury-OnThames, UK : Reconnaissance International, 2014. - P. 4.

4. Carol Wax. The Mezzotint : History and Technique. Harry N. Abrams, Inc., 1990.

5. Звонцов В. М. Офорт. Техника. История / В. М. Звонцов, В. И. Шистко. СПб. : Аврора, $2004-270$ с.

6. Мильчин А. Э. Издательский словарь-справочник. - Изд. 3-е, испр. и доп. - М. : ОЛМА-Пресс, 2006. - 500 с.

7. Айзеншер И. Я. Техника офорта. Гравюра на металле : учеб. пособие для худож. учеб. заведений / под ред. М. В. Доброклонского. - Л.-М. : Искусство, 1939. - 207 с.

8. The Windmill, Rembrandt, 1641, Etching, 15-21.1 cm [Електронний peсурс]. - Режим доступу : https://www.metmuseum.org/toah/works-ofart/41.1.12/.

9. Тарас Шевченко. Полное собрание сочинений в 10-и томах. - К. : Изд. АН УССР, 1961, т. 7, кн. 1, № 97 (изображение), с. 40-41 (примечания).

10. Киричок Т. Ю. Зносостійкість банкнотної продукції : монографія / Т. Ю. Киричок. - К. : НТУУ «КПІ», 2014. - 324 с.

11. Хайди Толивер-Нигро. Технологии печати : учеб. пособие для вузов / Хайди Толивер-Нигро; Пер. с англ. Н. Романова. - М. : ПРИНТ-МЕДИА центр, 2006. - 232 с.

12. Стефанов С. И. Путеводитель в мире печатних технологий. - М. : УНИСЕРВ, 2001. - $224 \mathrm{c}$.

13. Киричок П. О. Методи захисту цінних паперів та документів суворого обліку / П. О. Киричок, Ю. М. Коростіль, А. В. Шевчук. - К. : НТУУ «КПІ», 2008. - 368 c.

14. Intaglio Prints. Bureau of Engraving and Printing (ВЕР). [Електронний pecypc]. - Режим доступу : http://www.moneyfactorystore.gov/intaglioprints.aspx. 
15. National Printing Bureau intaglio print art work commemorating Tokyo Station's 100th anniversary. [Електронний ресурс]. - Режим доступу : http://www.npb.go.jp/en/news/20150129 tokyostation/index.html.

\section{References}

1. 50th Independence Comemmorative Note. Maldives Monetary Authority. Retrieved from http://mma.gov.mv/\#/currency/numismatic [in English].

2. COLLECTING BANKNOTES. Reserve Bank of Australia. Retrieved from https://banknotes.rba.gov.au/resources/for-collectors/collecting-banknotes/ [in English].

3. Kazhmuratov, Zhomart. (2014). Innovation and Art in the New 20,000 Tenge Note. Proceedings of the Pan European High Security Printing Conference (Milan, Italy, February 17-19, 2014), p. 4. Sunbury-On-Thames, UK: Reconnaissance International [in English].

4. Wax, Carol. (1990). The Mezzotint: History and Technique. Harry N. Abrams, Inc. [in English].

5. Zvoncov, V. M. \& Shistko, V. I. (2004). Ofort. Tehnika. Istorija [Etching. Equipment. History]. Saint Petersburg: Avrora [in Russian].

6. Mil'chin, A. Je. (2006). Izdatel'skij slovar'-spravochnik [Publishing dictionary-reference]. Moscow: OLMA-Press [in Russian].

7. Ajzensher, I. Ja. (1939). Tehnika oforta. Gravjura na metalle [Technique of etching. Engraving on metal]. Leningrad-Moscow: Iskusstvo [in Russian].

8. The Windmill, Rembrandt, 1641 , Etching, $15-21.1 \mathrm{~cm}$. Retrieved from https://www.metmuseum.org/toah/works-of-art/41.1.12/ [in English].

9. (1961). Taras Shevchenko. Polnoe sobranie sochinenij v 10-i tomah [Taras Shevchenko. Complete works in 10 volumes], vol. 7, book 1, \# 97. Kiev: Izd. AN USSR [in Russian].

10. Kyrychok, T. lu. (2014). Znosostiikist banknotnoi produktsii [The durability of banknote products]. Kyiv: NTUU 'KPI' [in Ukrainian].

11. Toliver-Nigro, Hajdi (2006). Tehnologii pechati [Printing technologies]. Moscow: PRINT-MEDIA centr [in Russian].

12. Stefanov, S. I. (2001). Putevoditel' v mire pechatnih tehnologij [Guide in the world of printing technologies]. Moscow: UNISERV [in Russian].

13. Kyrychok, P. O. \& Korostil, lu. M. \& Shevchuk, A. V. (2008). Metody zakhystu tsinnykh paperiv ta dokumentiv suvoroho obliku [Methods of protection of securities and documents of strict accounting]. Kyiv: NTUU 'KPI' [in Ukrainian].

14. Intaglio Prints. Bureau of Engraving and Printing (BEP). Retrieved from http://www.moneyfactorystore.gov/intaglioprints.aspx [in English].

15. National Printing Bureau intaglio print art work commemorating Tokyo Station's 100th anniversary. Retrieved from http://www.npb.go.jp/en/news/ 20150129 tokyostation/index.html [in English].

\footnotetext{
Проведено исследование и анализ современных тенденций и подходов в выборе изображений для печатной сувенирной продукции изготавливаемой Банкнотно-монетными дворами мира. Результаты исследований показывают, что в большинстве стран мира,
} 
а прежде всего в Украине, Банкнотно-монетные дворы не производят имиджевую печатную сувенирную продукцию, в частности интаглиопечатью.

Поэтому, развитие этой темы является современным, перспективным и конкурентоспособным, где главной идеей будет освещение национальной идентичности страны, ее истории и культуры, выдающихся деятелей и знаменательных событий, дат на государственном уровне.

Ключевые слова: интаглиопечать; офорт; глубокая печать; изображение; печатная сувенирная продукция; банкноты; Банкнотно-монетныйдвор.

The research and analysis of modern tendencies and approaches of the image selection for printed souvenir production made by the Mint and Stamp Printing House Departments of the world were undertaken. The research results show that in most countries of the world, and especially in Ukraine, the Mint and Stamp Printing House Departments do not produce image printed souvenirs, using the intaglio printing in particular. Thus, the development of this topic is up-to-date, promising and competitive vector, the main idea of that is supposed to be an illustration of the national identity of the country, its history and culture, prominent figures and significant events, dates at the state level.

Keywords: intaglio printing; etching; gravure printing; image; printed souvenirs; banknotes; Banknote and Mint. 